\title{
State reform in the Russian Federation at the present stage: challenges and threats
}

\author{
Maria Ivanovna Rosenko ${ }^{11}$, Elena Vladimirovna Skrebets $^{2}$, Sergey Andreevich \\ Zaporozhets $^{1}$, Svetlana Vitalievna Golikova ${ }^{4}$ and Bladimir Denis Rivera Siles ${ }^{4}$ \\ ${ }^{1}$ Sevastopol State University, Institute of Law, Department of Constitutional and Administrative Law, \\ Sevastopol, Russia \\ ${ }^{2}$ Sevastopol State University, Institute of Law, Department of Theory and History of State and Law, \\ Sevastopol, Russia \\ ${ }^{3}$ Sevastopol State University, Institute of Law, Department of Employment Law, Sevastopol, Russia \\ ${ }^{4}$ Drug Enforcement Administration of the National Police of Nicaragua, Nicaragua
}

\begin{abstract}
The purpose of the study is to identify the content of modern administrative reform and the characteristics of its impact on the quality and efficiency of public administration in Russia. The methodological basis of the study includes the dialectical, systemic, comparative historical and comparative legal approaches. The formal legal method, methods of data collection, analysis of secondary data, methods of analysis, induction, legal comparative studies were also used herein. The results of the study showed that state reform, contributing to a successful democratic transition to a developed social and legal state, is implemented by eliminating excessive centralization of state power, creating conditions for business development, removing excessive government interference and administrative barriers, ensuring competition and countering corruption. The introduction of criteria for the effectiveness of performance evaluation, monitoring and public control of the state apparatus contributes to real public control. Based on the results of the study, priority trends in the deployment of modern state reform were identified and the author's recommendations for its further improvement were formulated. Moreover, it was noted that the central directions of improving the system of public administration, in which systematic work is being carried out are the reduction of excessive government regulation; improving the quality of public services; increasing the efficiency of government bodies; increasing information transparency, overcoming corruption. The novelty of the work lies in the identified features of the political and administrative culture of Russia in the context of its constructive influence on the nature of modern administrative reform. Moreover, it includes the implementation of a systematic analysis of the modern Russian administrative reform and a comprehensive assessment of its results, consisting not only in improving the quality of public services provided to the population, but also in strengthening the vertical of executive power. Proposals have been developed to improve the organizational and legal mechanisms of state reform.
\end{abstract}

Keywords: state reform, administrative reforms, government bodies, state and municipal services

${ }^{1}$ Corresponding author: mariyair@mail.ru 
One of the key factors for the successful economic development of Russia in the modern world is the quality of public administration.

To create a modern, successful state at the international level, it is required to build a system of public administration corresponding to the specifics and scale of the country, receptive to progressive technological and communication solutions, and most importantly, meeting the needs of society in a convenient, open state [1,2]. The modern configuration of the system of international relations, the challenges and threats facing the Russian society, the resulting need to take measures to adjust the state development strategy, actualizes the search for effective mechanisms of public administration and, in this regard, the main approaches to state reform in various spheres of public relations [3]. Reforming the administrative and political sphere seems to be relevant at the present stage.

\section{Methods}

The methodological basis of the research includes a systematic approach to the problem under study. A comprehensive analysis of the works of foreign and domestic specialists related to the topics of public administration and administrative reforms, regulatory acts of the Russian Federation, and monitoring of publications in print and electronic media was applied. In the course of the research, the following data collection methods were used: analysis of regulations of the Russian Federation; monitoring of print and electronic media; analysis of secondary data related to the subject of study (sociological surveys, reports on the work done by direct participants in the reform, expert opinions on intermediate results and possible prospects for administrative reform). Directly in the process of research, a comparative-historical approach specific to political science was used.

The study was also based on a dialectical approach to the disclosure of legal phenomena and processes using general scientific (systemic, logical, analysis and synthesis) and specific scientific (formal legal and comparative legal) methods. The methods of normative and functional comparison made it possible to identify the mechanisms laid down in constitutional norms, through which it is possible to influence important institutions in the public administration system, including the institution of public service [4, 5].

\section{$3 \quad$ Results}

1. By means of a comparative-historical approach, the features of the political and administrative culture of Russia are revealed in the context of its constructive influence on the nature of modern administrative reform.

2. A systematic analysis of the modern Russian administrative reform was carried out and a comprehensive assessment of its results was carried out, consisting not only in improving the quality of public services provided to the population, but also in strengthening the vertical of executive power.

3. The periodization of the main stages of modern administrative reform has been developed, its main activities at the current stage have been studied in terms of their impact on the social efficiency of public administration, and the prospects for the formation of a social state in modern Russia have been determined.

4. Proposals have been developed to improve the organizational and legal mechanisms, taking into account the risks, challenges and threats facing the state in a democratic transition. 


\section{Discussion}

Analysis of the essence of administrative reforms, their types, goals and main components made it possible to identify the main key areas in which these reforms are being implemented: decentralization, deconcentration, privatization.

Analysis of the individual stages of the administrative reform in the Russian Federation ((1993-1995), (1996-2001), (2002-2007), (2008-2013), (2016-2018), (2019 to date)), its goals, objectives and main directions have shown the depth of the reform processes, thoughtfulness and balanced decision-making, progressive dynamics. Meanwhile, the incomplete fulfillment of the set goals, caused by a number of subjective and objective reasons, is observed. The measures taken in the course of modernization of the state management system, in general, resolved the issues facing it and provided a solid foundation for the administrative reform, which is being implemented at the present stage $[2,6,7]$.

The President's orientation towards the idea of strengthening the state in combination with the implementation of socio-economic liberalization and pragmatic defense of the national interests of the state in the international arena predetermined a special interest in the experience of state reform of other states, including the introduction of the ideas of "new managerialism" into public administration [8]. The reforming of the Russian administrative system using the methods of "new public management" was seen as a key condition for maintaining high rates of economic growth [9]. However, Public Administration gives way to Public Management [10-12]. When forming the main documents in accordance with which the state reform is being carried out in the Russian Federation, the interests of citizens (priorities of 2011) were taken into account and the tasks relevant for the economy and the state were identified, which corresponds to the approaches developed by the UN [13].

The activities planned for the near and medium term (until 2024) relate to the improvement of the management model by introducing new personnel technologies and reducing financial costs for the management system itself by reducing costs by using the digitalization of the economy and the digitalization of public administration. Possible risks in the implementation of administrative reform measures and their negative consequences are noted, as well as proposals for improving approaches to the modernization of public administration, which can significantly increase the effectiveness of the reforms:

1. In terms of the absence at the present stage of widespread coverage of high-speed Internet and the cognitive capabilities of the older generation of their use, the optimization of the number of civil servants by establishing quantitative parameters for the reduction of the number and staff may lead to a deterioration in the population's perception of the activities of civil servants due to the fact that the quality of the services provided, their terms, the frequency of applications for the same service can be significantly inferior to the achieved indicators.

It seems inappropriate to reduce the costs of maintaining the state apparatus by releasing some of the employees of multifunctional centers and civil servants engaged in providing public services to the population.

2. Due to the fact that all significant decisions in the field of reforming the public administration system are made at the level of the governor and the executive branch of government, the likelihood of risks increases, both inherent in the very concept of the new public administration and associated with the limited institutional environment of the region (underdevelopment civil society, market institutions). The likelihood of risks will be enhanced by the possibility of not including information on the mistakes made in the reporting. 
In this regard, it is proposed to improve the mechanism for creating an export community and public councils under state authorities by ensuring transparency, publicity in the formation and mandatory discussion of candidates at public hearings, as well as a gradual rotation of representatives of the public.

3. Annual monitoring of the quality and availability of public services, studies of the degree of satisfaction of citizens with the quality of the activities of state authorities and local governments and the implementation of control and supervisory functions have shortcomings. There is a danger of using a certain model of a sociological survey sample, which can significantly distort the actual perception by citizens of the quality and efficiency of public administration (the work of a government body, obtaining public services, creating a favorable environment for business). An imperfect assessment of the effectiveness and efficiency of a public administration body or a separate service can lead to socio-political tension with the appearance (artificially created) of citizens' satisfaction.

It is proposed to improve the methodology of polling citizens by creating a service on the WEB-page with the ability of the respondent to express his or her opinion, and not only on the issues included in the program.

4. The achieved results in reducing corruption show a decrease in these indicators at the present stage, which is due to the adaptation of the subjects of corruption to the new conditions. According to the results of the anti-corruption study, it seems appropriate to introduce the following approaches: the introduction of criminal liability for enrichment on behalf of a legal entity, the introduction of responsibility for lobbying the interests of certain financial and industrial groups and the liability of corporations - exporters for bribery and bribery of officials.

5. The Digital Economy program assumes that citizens with the appropriate qualifications will work in the civil service in the new conditions. It seems applicable to provide for certain state guarantees for redundant civil servants of pre-retirement age, proceeding from the following considerations: their training may cost more than the effect obtained; social support in the form of an early pension can significantly relieve social tension and make both the introduction of new digital technologies and the psychological climate in the team more comfortable.

\section{Conclusion}

The directions of reform, their essential aspects, timeliness and quality are determined by the readiness of the state authorities to respond to the challenges and threats facing the state and society, to realize and understand the level of compliance of managing relations with the level of development of public relations at a certain stage. Only then, as noted in studies $[10,11,14,15]$, the goal can be achieved.

According to the experience of implementing state reforms in some European states [9, $11,14]$ and in the Russian Federation, their content in terms of the composition of events, approaches, ideology cannot be divided into individual reforms. Each new stage of state reform is due to a new level of socio-political relations, the adjustment of goals, taking into account the achievement of the tasks set.

\section{References}

1. A.G. Barabashev, A.V. Klimenko, Sostoyanie i napravleniya reform rossiiskogo gosupravleniya [State and directions of reforms in Russian public administration], in WP8 Series "State and Municipal Administration" (Pub. House of the Higher School of Economics, Moscow, 2017) 
2. E.A. Pashkovsky, Administrativnaya reforma kak faktor povysheniya effektivnosti gosudarstvennogo upravleniya v sovremennoi Rossii [Administrative reform as a factor in increasing the efficiency of public administration in modern Russia] (Publishing house A.I. Herzen, Saint Petersburg, 2013)

3. M.A. Feldman, Manag. Iss. 5(42) (2016)

4. Ya.I. Kuzminov, A.B. Zhulina (eds.), Administrativnaya reforma i sokrashchenie kontrolno-nadzornykh funktsii (tezisy doklada "Perspektivy administrativnoi reformy v Rossii") [Administrative reform and reduction of control and supervisory functions (theses of the report "Perspectives of Administrative Reform in Russia")]. Accessed on: June 27, 2021. [Online]. Available: https://www.hse.ru/data/2016/06/21/1116116123/Administrative\% 20reform.pdf

5. G.L. Kupryashin, Public Administ. 58, 5-8 (2016)

6. V.G. Vishnyakov, Administrativnaya reforma: 15 let poiskov kontseptsii [Administrative reform: 15 years of searching for a concept]. Accessed on: June 27, 2021. [Online]. Available: http://www.justicemaker.ru/view-article.php?id=25\&art=2792

7. R.M. Vulfovich, Manag. Consult. 12, 102-107 (2017)

8. G. Hammerschmid, S. Van de Walle, A. Oprisor, V. Stimac, Trends and Impact of Public Administration Reforms in Europe: Views and Experiences from Senior Public Sector Executives (2013). Accessed on: June 27, 2021. [Online]. Available: https://ec.europa.eu/info/sites/default/files/research_and_innovation/research_by_area/ documents/ssh_briefs/cocops-policy-brief.pdf

9. Y. Han, K. Hwang, Pub. Pers. Manag. 49(3), 393-420 (2020). https://doi.org/10.1177/0091026019873031

10. A. Ingrams, S. Piotrowski, D. Berliner, Perspec. Pub. Manag. Govern. 3(4), 257-272 (2020). https://doi.org/10.1093/ppmgov/gvaa001

11. K. Hwang, Int. J. Organiz. Analysis 27(3), 630-643 (2018). https://doi.org/10.1108/IJOA-02-2018-1356

12. Administrativnaya reforma: sovershenstvovanie gosudarstvennogo upravleniya $v$ RF [Administrative reform: improving public administration in the Russian Federation] Accessed on: June 27, 2021. [Online]. Available: https://ar.gov.ru

13. Public Administration Reform. Practice Note. United Nations Development Program. Accessed on: June 27, 2021. [Online]. Available:

https://www.undp.org/content/undp/en/home/librarypage/capacity-building/public-adm inistration-reform-practice-note.html

14. C. Greve, N. Ejersbo, P. Lægreid, T. Christensen, Intern. J. Pub. Admin. 43(8), 1-14 (2019). https://doi.org/10.1080 / 01900692.2019.1645688

15. A.S. Seif, Public Administration Reform: Policy Critiqueppad. Accessed on: June 27, 2021. [Online]. Available:

//https://www.academia.edu/3613907/UNDPs_Note_on_Public_Administration_Refor m_Policy_and_Approach_Critique 